\title{
MIĘDZYOSOBOWY POZIOM WYJAŚNIANIA UMYSŁU I ZDOLNOŚCI POZNAWCZYCH
}

\begin{abstract}
THE INTERPERSONAL LEVEL OF EXPLANATION OF MIND AND COGNITION

What is the influence of the social and (to a lesser extent) the cultural on mind and cognition? The question will concern: (i) the nature of the relation between what is social and cultural, on the one hand, and the mind, cognitive ability, and cognitive development on the other; (ii) aspects of the mind, cognitive ability, and cognitive development affected by what is social and cultural; (iii) processes in which what is social and cultural becomes a part of individual cognitive functioning. This paper attempts to provide a conceptual framework within which the above questions can be answered. In the literature concerning the explanation of mind and cognitive abilities, attention is drawn to the importance of distinguishing levels of explanation. One of such approaches to multi-level explanation of the mind and cognition is the distinction drawn by Daniel Dennett between the personal level of explanation (e.g., level of beliefs, desires) and the subpersonal level of explanation (e.g., neural or computational). The purpose of this article is to argue that - recognising that the social and the cultural are one of the constitutive conditions of mind and cognition - we should posit a third level: the interpersonal level of explanation (ILE). The reason for postulating ILE is that there are specific domains in which interpersonal interactions affect elementary cognitive abilities and processes, which may thus result in their transformation into higher cognitive abilities and processes. The entire group of such domains will be defined as ILE, and at the centre of its explanatory potential will be the different types and forms of the said transformation. One of the main research objectives pursued at the ILE is to identify and formulate a taxonomy of transformative features and processes. Two models of such processes will be presented: the Vygotsky model and the Tomasello model. In the final part of this paper, the basic methodological assumptions of the ILE will be presented: the relative autonomy of this level of explanation, multi-level analysis, and the mechanism-based explanation. These assumptions will also be used to formulate general theses of the ILE.
\end{abstract}

Keywords: the interpersonal level of explanation of mind, social mechanisms of mind transformation, the shared intentionality hypothesis, dialogic thinking, Vygotsky's theory, Tomasello's theory, mechanism-based explanation

* Katedra Kognitywistyki, Uniwersytet Mikołaja Kopernika w Toruniu, Fosa Staromiejska 1A, 87-10o Toruń, e-mail: d.zuromski@umk.pl, ORCID: https://orcid.org/oooo-ooo24854-2306. 
Na czym polega rola tego co społeczne i kulturowe w konstytuowaniu umysłu oraz poznania? Potrzebę znalezienia odpowiedzi na to pytanie podkreśla m.in. Robert Poczobut w książce Między redukcją a emergencją. Spór o miejsce umystu $w$ świecie fizycznym. Wysuwając wątpliwości wobec modularnych koncepcji umysłu, zauważa:

Do tego, by percypować, myśleć, mówić, pamiętać, przeżywać zazdrość lub irytację, niezbędny jest modularny mózg o określonej organizacji funkcjonalnej. Jest niezbędny, lecz niewystarczający. Wytworzenie umysłu wymaga znacznie więcej niż architektury modularnej. [...] Do ujęcia całościowego konieczne jest również uwzględnienie sieci relacji interpersonalnych $i$ społecznych, których uczestnikiem jest dana jednostka (Poczobut 2009: 430-431, moje podkreślenie).

Nawet jednak ci autorzy, którzy postulują konieczność uwzględnienia czynnika społecznego w „wytworzeniu umysłu”, rzadko przedstawiają propozycje, które realizowałyby ten postulat. Celem tego artykułu jest więc odpowiedź na pytanie, na czym polega wpływ tego co społeczno-kulturowe na umysł i poznanie. Pytanie to dotyczy (por. Gauvain, Perez 2015):

natury relacji między tym co społeczne i (w mniejszym stopniu) kulturowe a umysłem, zdolnościami poznawczymi i rozwojem poznawczym,

(ii) aspektów umysłu, zdolności poznawczych i rozwoju poznawczego, na które wpływ ma to co społeczne i kultura,

(iii) procesów, w których to co społeczne i kulturowe staje się częścią indywidualnego funkcjonowania poznawczego.

$\mathrm{W}$ artykule przedstawiam propozycję pewnej ramy pojęciowej, dzięki której można udzielić odpowiedzi na kwestie (i)-(iii). Nie tyle skupiam się przy tym na społeczno-kulturowej koncepcji umysłu i poznania, ile - uznając, że to co społeczne i kulturowe jest jednym z konstytutywnych warunków umysłu i poznania (por. Carpendale, Frayn, Kucharczyk 2016) - postuluję mówienie o międzyosobowym poziomie wyjaśniania.

Wielu badaczy - m.in. George Herbert Mead, Lew Wygotski, Jerome Bruner, James V. Wertsch czy Michael Tomasello - wskazywało na konstytutywną rolę tego co społeczno-kulturowe dla umysłu i poznania, przeciwstawiając się dawnej i obecnej dominacji badań skupionych na procesach zachodzących w podmiotach jednostkowych (indywidualizm metodologiczny)1. Mój projekt ukazania koniecznej roli czynnika społecznego i kulturowego w kształtowaniu umysłu nie ma jednak charakteru redukcjonistycznego. Nie usiłuję spro-

\footnotetext{
${ }^{1}$ Historyczny przegląd i teoretyczne opracowanie tej idei można znaleźć u Valsinera i van der Veera (2000).
} 
wadzić jednego czynnika (jednostkowego podmiotu) do drugiego (społecznokulturowego). Badanie złożoności umysłu i poznania wymaga podejścia interdyscyplinarnego, dla którego odpowiedniejsza jest analiza wielopoziomowa, a nie redukcjonizm. Pisząc o poznaniu społecznym, Piotr Winkielman zauważa:

W tym kontekście warto podkreślić różnicę między analizą wielopoziomową a redukcjonizmem. Redukcjonizm zakłada, że jeden (przeważnie niski) poziom analizy jest „lepszy” od innych poziomów i celem nauki powinno być sprowadzanie wyjaśnień do tego poziomu. Analiza wielopoziomowa zakłada, że każdy poziom oferuje unikalną perspektywę i ujawnia zależności i struktury niewidoczne na innych poziomach (Winkielman 2008: 14).

W literaturze dotyczącej wyjaśniania zachowania, umysłu i zdolności poznawczych podkreśla się wagę rozróżniania poziomów wyjaśniania. Wyróżnia się przede wszystkim²:

1 .

podmiotowy poziom wyjaśniania (PPW) - poziom przekonań, pragnień itp.

2.

subpodmiotowy poziom wyjaśniania (SPW) - np. poziom neuronalny lub komputacyjny.

Ten artykuł ma na celu wykazanie, że powinniśmy przyjąć jeszcze trzeci poziom:

3. międzyosobowy poziom wyjaśniania (MPW).

Trzeci poziom wyjaśniania postuluje się ze względu na istnienie szczególnych obszarów, w których interakcje międzyosobowe wpływają na podstawowe zdolności i procesy poznawcze; może to prowadzić do ich transformacji w bardziej zaawansowane zdolności i procesy poznawcze. Ogół takich obszarów będę nazywał międzyosobowym poziomem wyjaśniania zdolności poznawczych (MPW), a w centrum jego potencjału eksplanacyjnego będą znajdować się różne typy i formy tej transformacji. Tak więc celem artykułu, by jeszcze raz odwołać się do cytatu z Poczobuta, nie jest próba zarysowania „ujęcia całościowego” umysłu, lecz wskazanie na istotność MPW w wyjaśnieniu „wytwarzania umysłu”. Ponadto, przedstawiając zarys MPW, będę koncentrował się głównie na aspekcie społecznym wyjściowego pytania oraz na w miarę szczegółowym opisie wybranych przykładów procesów charakterystycznych dla MPW.

Artykuł jest podzielony na dwie zasadnicze części. Pierwsza dotyczy „treści” MPW, to jest ukazuje MPW jako poziom społecznych mechanizmów trans-

2 Podział na podmiotowy i subpodmiotowy poziom wyjaśniania został wprowadzony przez Daniela Dennetta i przyjął się w literaturze jako neutralny (tj. niezobowiązujący do konkretnej ontologii) oraz niezależny od szczegółowych koncepcji Dennetta. W kwestii rozumienia tego podziału przez Dennetta por. np.: Drayson 2014, w kwestii jego rozumienia przez różnych autorów por. Drayson 2012. 
formacji umysłu. Przedstawię dwa modele tak rozumianej transformacji: klasyczny, ,językowy” model Wygotskiego oraz model Tomasella. Zgodnie z pierwszym z nich socjogeneza wyższych funkcji umysłowych jest wynikiem internalizacji semiotycznie zapośredniczonych interakcji międzyosobowych. Podstawowym mechanizmem transformacji umysłu w tym modelu jest dialogiczność. Natomiast w modelu Tomasella, będącym odnowieniem, kontynuacją, ale i istotnym rozszerzeniem podejścia Wygotskiego ${ }^{3}$, kładzie się nacisk na procesy i mechanizmy transformujące o charakterze przedjęzykowym, jak np. intencjonalność dzieloną (shared intentionality) ${ }^{4}$. W obu modelach wyższe funkcje umysłowe są zarazem zdolnościami specyficznie ludzkimi, a ich podstawową funkcją jest samoregulacja.

W drugiej części artykułu skupiam się na ogólniejszym sformułowaniu tez MPW i przedstawieniu jego podstawowych założeń metodologicznych: względnej autonomiczności tego poziomu wyjaśniania, analizy wielopoziomowej oraz modelu wyjaśniania opartego na mechanizmach (mechanism-based explanation). Założenia te służą również do sformułowania ogólnych tez MPW.

\section{KLASYCZNY MODEL WYGOTSKIEGO: SPOŁECZNO-KULTUROWA KONCEPCJA UMYSŁU}

Teoria Wygotskiego, nazywana także społeczno-kulturową koncepcją umysłu i poznania, jest klasyczną teorią umysłu i procesów poznawczych, która może posłużyć za model dla MPW5. Teoria ta opiera się na trzech istotnych założeniach (Wertsch 1985: 14-15, Fernyhough 2008: 227). Są to:

\footnotetext{
3 Sam Tomasello określa swą teorię mianem A Neo-Vygotskian Theory (Tomasello 2019: 297, 304).

${ }^{4}$ Idea społecznych źródeł transformacji umysłu jest ekstrapolacją i interpretacją idei Wygotskiego i Tomasella. Stanowisko Tomasella omawiam nieco szerzej w (Żuromski 2016). W artykułach (Kern, Moll 2017) oraz (Moll 2016) autorki przedstawiają dwa podejścia do intencjonalności dzielonej (kolektywnej): transformatywne i addytywne, argumentując za pierwszym stanowiskiem i przypisując Tomasellowi to drugie stanowisko (lub wahanie między pierwszym a drugim). Tomasello (2016d) odrzuca taką interpretację. W artykule (Żuromski 2020) przedstawiam alternatywne wobec autorek ujęcie intencjonalności dzielonej jako międzyosobowego mechanizmu transformacji umysłu.

5 Należałoby tu mówić raczej o zmodyfikowanym modelu Wygotskiego (Neo-Vygotskian), ponieważ model ten odwołuje się również do opracowań psychologów rozwojowych, np. Jamesa V. Wertscha (1985) i Charlesa Fernyhougha (1996, 1997, 2008), którzy nie tylko poddali model Wygotskiego krytycznej analizie i skonfrontowali go z współczesnymi badaniami, lecz również sami twórczo rozwijali.
} 
(i)

idea oparcia badań nad zjawiskami umysłowymi na „metodzie genetycznej";

teza, że wyższe funkcje i procesy umysłowe jednostki mają swe źródła w aktywnościach społecznych, a ściślej „interpsychologicznych";

teza, że zrozumienie wyższych funkcji umysłowych oraz ich rozwoju może być osiągnięte dzięki zrozumieniu funkcji mediacyjnej kulturowych „narzędzi psychologicznych”, takich jak znaki, w owych procesach.

Zgodnie z metodą genetyczną funkcjonowanie ludzkiego umysłu może być zrozumiane tylko z punktu widzenia jego rozwoju od funkcji i form elementarnych do funkcji i form wyższych i bardziej złożonych. W tym kontekście Wygotski wyróżniał elementarne funkcje umysłowe, które przeciwstawiał wyższym funkcjom umysłowym. Rozróżniał również „naturalną” oraz „społeczno-kulturową" linię rozwoju funkcji umysłowych. Rodzimy się zgodnie z konstytucją naszego gatunku uposażeni biologicznie w pewien zasób zdolności poznawczych, tj. elementarne funkcje umysłowe. Po dość krótkim rozwoju tych funkcji w ramach naturalnej linii rozwoju (około drugiego roku życia) elementarne funkcje umysłowe ulegają rewolucyjnej ${ }^{6}$, jakościowej transformacji w wyniku zderzenia się dwóch linii rozwoju: naturalnej i kulturowej. W rezultacie tego zdarzenia dzięki semiotycznemu zapośredniczeniu procesów umysłowych i włączeniu znaku („narzędzi psychologicznych”) do struktury elementarnych funkcji umysłowych, dokonuje się ich reorganizacja w wyższe funkcje umysłowe. Te ostanie charakteryzują tylko ludzki aparat poznawczy i nie sposób wyjaśnić wyższych funkcji umysłowych za pomocą zasad i praw metodologicznych stosowanych w wyjaśnianiu elementarnych funkcji umysłowych (Wertsch 1985: 24)7. Przykładami takich funkcji umysłowych są pamięć, uwaga, percepcja i myślenie. Wertsch wymienia cztery główne kryteria różniące elementarne i wyższe funkcje umysłowe:

\footnotetext{
${ }^{6}$ Ten sposób opisu jest również charakterystyczny dla Tomasella (2002), który wskazuje na „rewolucję dziewiątego miesiąca” jako na czas pojawienia się w rozwoju specyficznie ludzkich zdolności poznawczych. W teorii Wygotskiego można w analogiczny sposób mówić o rewolucji 24 miesiąca.

7 Por. np.: „Historia rozwoju każdej wyższej funkcji psychicznej nie jest prostą kontynuacją i dalszym doskonaleniem się elementarnych funkcji. Jest ona radykalną zmianą kierunku rozwoju elementarnych funkcji i przekształceniem procesu, występującego w zupełnie nowej formie: każda wyższa funkcja psychiczna jest więc specyficzną, nową formą działalności psychicznej” (Wygotski 2006: 63).
} 
(1) przesunięcie kontroli ze środowiska na jednostkę, to jest pojawienie się regulacji wolicjonalnej; (2) pojawienie się świadomej realizacji procesów umysłowych; (3) społeczne pochodzenie i społeczny charakter wyższych funkcji umysłowych; i (4) używanie znaków do pośredniczenia w wyższych funkcjach umysłowych (Wertsch 1985: 25).

Natomiast elementarne funkcje umysłowe charakteryzuje odpowiednio:

(1) fakt, że kontrola tych funkcji jest zdeterminowania przez środowisko naturalne; (2) brak świadomej realizacji procesów umysłowych; (3) indywidualne źródła czy pochodzenie procesów umysłowych oraz (4) brak mediacji procesów umysłowych za pomocą znaków (Wertsch 1985: 27) .

Taka charakterystyka wskazuje, że elementarne funkcje umysłowe są podporządkowane sztywnym reakcjom organizmu na środowisko zewnętrzne. Funkcje wyższe, zapośredniczone semiotycznie przez znaki, hamując naturalne reakcje oraz podporządkowując je świadomym procesom wolicjonalnym, umożliwiają samoregulację 9 .

Ogólne pojęcia metody genetycznej oraz rozwoju nabierają konkretnej treści, jeśli przyporządkuje się je do określonej domeny genetycznej, z właściwymi dla niej zasadami oraz narzędziami psychologicznymi, które umożliwiają odpowiednie dla danej domeny transformacje funkcji umysłowych. Wertsch (1985: 54) wyróżnia cztery domeny, do których Wygotski stosował metodę genetyczną. Są to: domena filogenetyczna, w której zdolności poznawcze człowieka postrzega się i bada jako rozwinięte formy zdolności poznawczych małp człekoksztaltnych; domena historii społeczno-kulturowej, w której bada się pojawienie się kulturowych „narzędzi psychologicznych” takich jak narzędzia i znaki - zmiany ich form oraz ich wpływ na rozwój i transformacje funkcji umysłowych; domena ontogenetyczna, badająca dynamiczną interakcję naturalnej (biologicznej) i społeczno-kulturowej linii rozwoju jednostki ludzkiej; oraz domena mikrogenezy (microgenesis).

Kolejna idea Wygotskiego dotyczy społecznego pochodzenia wyższych funkcji umysłowych. Przede wszystkim Wygotski kładł nacisk na szczególny rodzaj procesów społecznych, które Wertsch określił mianem „interpsychologicznych", a które:

\footnotetext{
${ }^{8}$ Interesującą analizę wyższych funkcji umysłowych podaje Toomela (2016: 91), który określa je jako: (1) systemy psychologiczne, (2) rozwijające się z procesów naturalnych, (3) w których pośredniczą symbole; (4) formy współpracy psychologicznej, które są (5) internalizowane w trakcie rozwoju (6); produkty rozwoju historycznego, (7) świadome i (8) zależne od woli; (9) aktywne formy adaptacji do środowiska, (10) dynamicznie zmieniające się w rozwoju, oraz (11) ich ontogeneza rekapituluje historię kultury.

9 We współczesnej literaturze ten wątek koncepcji Wygotskiego jest rozwijany w badaniach nad funkcjami zarządzającymi (executive functions) oraz rolą znaków czy języka jako systemu znaków w rozwoju funkcji zarządzających; por. zwłaszcza Müller i in. 2009 oraz np. Kielar-Turska 2013.
} 
obejmują małe grupy (często dwuosobowe) jednostek zaangażowanych w konkretne interakcje społeczne i można je wytłumaczyć w kategoriach dynamiki małych grup i praktyk komunikacyjnych (Wertsch 1985: 60).

Wygotski w odniesieniu do socjogenezy wyższych funkcji umysłowych sformułował ogólne prawo genetyczne rozwoju kulturowego:

wszelka funkcja w rozwoju kulturowym dziecka pojawia się na scenie dwukrotnie, w dwóch płaszczyznach: najpierw społecznej, później psychologicznej - najpierw między ludźmi, jako kategoria interpsychiczna, a następnie w wewnętrznym przeżyciu dziecka, jako kategoria intrapsychiczna. [...] Mamy podstawę uznawać tę tezę za prawo w pełnym znaczeniu tego słowa, ale jest oczywiste, że przejście z zewnątrz do wewnątrz przekształca sam proces, zmienia jego strukturę i funkcje. Wszystkie wyższe funkcje psychiczne i stosunki między nimi wywodzą się ze stosunków społecznych, z rzeczywistych stosunków między ludźmi (Wygotski 1971: 133).

Wyższe funkcje umysłowe są $\mathrm{w}$ swej pierwotnej postaci rozproszone czy też dzielone przez uczestników interakcji, na przykład matkę i dziecko, a następnie internalizowane i opanowane przez dziecko w celu samoregulacji (Fernyhough 1997) ${ }^{10}$. Najbardziej spektakularnym przykładem działania tego prawa są wyniki badania Wygotskiego nad związkiem między myśleniem a mową. Wygotski przedstawił - alternatywne wobec ujęcia Jeana Piageta - wyjaśnienie zjawiska mowy egocentrycznej (Fernyhough 1997). Mowa egocentryczna jest specyficzną formą zachowania językowego, w której dziecko, często np. podczas malowania, rysowania czy układania klocków, będąc samo lub w obecności innych, mówi na głos do siebie. We współczesnej literaturze przedmiotu fenomen ten jest określany neutralnie jako „mowa prywatna” - neutralnie, ponieważ pierwotna nazwa „mowa egocentryczna” podkreślała istotę stanowiska Piageta w wyjaśnieniu tego zjawiska ${ }^{11}$. Wyjaśnienie Piageta wskazywało na to, że główną przyczyną mowy egocentrycznej występującej u dzieci w wieku od trzeciego do siódmego roku życia jest niedostateczne „uspołecznienie mowy pierwotnie indywidualnej” (Wygotski 1989: 358), tj. niezdolność dostosowania swoich wypowiedzi do perspektyw innych (Berk 1992, Fernyhough 1997). Z tego punku widzenia zjawisko mowy egocentrycznej nie ma szczególnie doniosłego znaczenia dla psychologii rozwoju - wraz z uspołecznieniem perspektywy dziecka mowa egocentryczna właściwie zanika. Wyjaśnienie Wygotskiego jest natomiast oparte na wymienionych wyżej założeniach (i)-(iii). Wychodząc od analizy genetycznej, szukał on

\footnotetext{
${ }^{10}$ „Analiza ta [rozwojowa] pokazuje, że każda wyższa funkcja początkowo była szczególną formą współpracy społecznej i dopiero potem przekształca się w zachowanie indywidualne, interioryzując strukturę, która w głębi psychicznego systemu dziecka zachowuje wszystkie podstawowe cechy swej organizacji symbolicznej” (Wygotski 2006: 62).

${ }^{11}$ Oczywiście idea egocentryzmu w teorii Piageta jest elementem szerszej i bardziej podstawowej teorii rozwoju. W kwestii porównania teorii Piageta i Wygotskiego por. Carpendale, Lewis 2004, 2006.
} 
źródła mowy egocentrycznej i uznał za nie interakcje społeczne (Wygotski 1989: 358). Myślenie werbalne, czy też mowa wewnętrzna, pochodzi z mowy społecznej, a mowa egocentryczna stanowi etap pośredni procesu internalizacji.

Mowa egocentryczna ma podstawowe znaczenie dla rozwoju i wiąże się $\mathrm{z}$ mediacją semiotyczną procesów umysłowych. Wygotski kładł duży nacisk na konstytucyjną i zarządzającą funkcję języka względem procesów poznawczych (Müller i in. 2009). Mowa tworzy i zarazem zwiększa zasoby poznawcze oraz behawioralne dziecka. Internalizacja mowy społecznej, służącej za narzędzie kontroli oraz komunikacji z innymi, nadaje nową funkcję mówieniu - za pomocą mowy egocentrycznej dziecko może już samodzielnie regulować i kontrolować własne procesy mentalne i zachowanie (Müller i in. 2009, Fernyhough 1997). Mowa egocentryczna nie tyle zanika w procesie rozwoju, jak twierdził Piaget, ile staje się bezgłośną mową wewnętrzną, tj. myśleniem werbalnym.

W modelu Wygotskiego uwzględnione są konkretne procesy poznawcze, które mają swe źródła w semiotycznych interakcjach społecznych. W wyniku internalizacji tych interakcji powstają semiotycznie zapośredniczone procesy umysłowe, a tym samym elementarne funkcje umysłowe jednostki ulegają transformacji w wyższe funkcje umysłowe. Jednym z początkowych celów badawczych realizowanych na MPW jest zidentyfikowanie mechanizmów i procesów o charakterze transformatywnym, a następnie przeprowadzenie ich taksonomii. Niżej omawiam dwa takie mechanizmy: dialogiczność, ponieważ ,jak pisał Wygotski, prawdziwym przedmiotem internalizacji jest dialog” (Tomasello 2002: 257), a w szczególności dialogiczne myślenie i dialogiczne reprezentacje poznawcze, oraz intencjonalność dzieloną.

\section{DIALOGICZNOŚĆ JAKO MIĘDZYOSOBOWY MECHANIZM TRANSFORMACJI UMYSŁU}

Koncepcję dialogicznego umysłu oraz dialogicznego myślenia sformułował Charles Fernyhough (1996, 1997, 2008, 2009), rozwijając społeczno-kulturową koncepcję umysłu Wygotskiego, Michaiła Bachtina i Jamesa V. Wertscha ${ }^{12}$.

\footnotetext{
${ }^{12}$ Warto w tym miejscu przywołać teorię „Ja dialogowego” Huberta Hermansa, inspirowaną również m.in. koncepcjami Wygotskiego i Bachtina, a rozwijaną przez psychologów polskich (por. Puchalska-Wasyl 2016). W koncepcji tej przyjmuje się, że „kategoria dialogu jest podstawową zasadą opisu zarówno w odniesieniu do dynamiki zewnętrznych interakcji społecznych, jak i intrapsychicznych relacji wewnątrz Ja. Strukturalne i dynamiczne właściwości Ja są podobne do strukturalnych i dynamicznych właściwości społeczeństwa, co znalazło odzwierciedlenie w zaproponowanej przez Hermansa metaforze Ja jako społeczności umysłu (a society of mind)” (Bąk 2009: 56).
} 
Zgodnie z jej podstawowym twierdzeniem „wyższe funkcje umysłowe mają charakter dialogiczny" (Fernyhough 1996: 50). Jest to próba eksplikacji (i zarazem operacjonalizacji) twierdzenia, że myślenie jest procesem społecznym. Z tezy Wygotskiego dotyczącej socjogenezy wyższych form umysłowych wypływa ważna konsekwencja: „wyższe funkcje umysłowe zachowują przynajmniej niektóre cechy zewnętrznych interakcji, z których pochodzą" (Fernyhough 1997: 69). Taką właśnie cechą jest dialogiczność, ponieważ w wyniku internalizacji międzyosobniczych oddziaływań językowych - w tym wypadku dialogu zewnętrznego $-\mathrm{w}$ indywidualnym umyśle powstają formy poznania, które zachowują dialogiczną naturę tych interakcji (Fernyhough 2008: 232).

W ogólnym sformułowaniu można tę ideę przedstawić następująco: dialog zewnętrzny jest językową praktyką społeczną charakteryzującą się pewną dynamiką i naprzemienną strukturą, w której różne osoby, np. matka i dziecko, wchodzą ze sobą w interakcje. Przykładem takiej aktywności jest językowa praktyka społeczna oparta na strukturze pytanie-odpowiedź. Dziecko, uczestnicząc w niej, uczy się organizować swoje doświadczenie tak, aby prowadziło je ono do rozwiązania problemu. Dzieje się to podczas prostych zabaw, takich jak układanie puzzli. Na początku tego procesu matka może zadawać pewne pytania, a dziecko na nie odpowiadać. Następnie, zgodnie ze schematem internalizacji Wygotskiego, dziecko już samo inicjuje i odtwarza na głos w ramach mowy prywatnej strukturę pytanie-odpowiedź, tj. wzbudza w sobie perspektywę matki, zadaje na głos pytanie i samo na nie odpowiada. Innymi słowy, organizuje swoje doświadczenie za pomocą zinternalizowanej społecznej praktyki pytanie-odpowiedź.

Internalizacja takiego dialogu polega nie tyle na przyswajaniu wypowiedzi jego uczestników, ile na zdolności nabywania i podejmowania perspektyw jej uczestników ${ }^{13}$. Wynikiem aktywnej rekonstrukcji dialogu zewnętrznego na płaszczyźnie intrapsychicznej w postaci dialogu wewnętrznego jest zdolność jednostki do jednoczesnego utrzymania w umyśle co najmniej dwóch perspektyw, własnej oraz cudzej (Białek 2010). Tak więc zdaniem Fernyhougha istnieje klasa procesów poznawczych - dialogicznego myślenia - która jest wynikiem internalizacji językowych interakcji społecznych, czyli dialogu zewnętrznego (Fernyhough 2009: 42).

Fernyhough podaje kryteria przypisywania dialogiczności procesom umysłowym. Jego zdaniem procesy umysłowe można opisać jako dialogiczne, jeśli

${ }^{13}$ Chociaż opisując zjawisko perspektywiczności Fernyhough odwołuje się do bogatego kontekstu wyjaśnień tego pojęcia, to dla uproszczenia można uznać, że internalizacja dialogu zewnętrznego umożliwia tworzenie swoistych reprezentacji językowych - reprezentacji dialogicznych czy perspektywicznych (por. niżej) - których zadanie polega na wzbudzaniu we własnym umyśle perspektyw uczestników dialogu. 
(i) wiążą się z równoczesnym utrzymaniem wielu perspektyw; (ii) perspektywy te są reprezentowane w systematycznie interpretowalnym systemie znaków, takim jak język naturalny; (iii) perspektywy są w sposób elastyczny skoordynowane; (iv) zachowują triadyczność relacji intencjonalnych dialogu zewnętrznego; (v) współdziałają ze sobą w dynamicznej grze, która jest otwarta i samoregulująca (Fernyhough 2009: 43-45).

$\mathrm{W}$ ontogenezie proces powstawania dialogu wewnętrznego jako internalizacji semiotycznie zapośredniczonych interakcji społecznych jest wieloetapowy (Fernyhough 2008: 236). Podstawową metodologią badań tego procesu są badania nad mową prywatną. Temu procesowi w ścieżce rozwojowej towarzyszą istotne procesy dotyczące zarówno językowej strony dialogu, jak i samej struktury tego dialogu. $\mathrm{W}$ tym pierwszym aspekcie reprezentacja językowa myślenia dialogicznego $\mathrm{w}$ postaci zinternalizowanej przechodzi różne przeobrażenia, syntaktyczne i semantyczne, w wyniku których myślenie dialogiczne przestaje mieć explicite strukturę dialogiczną. Drugi aspekt dotyczy zanikania struktury dialogu, czyli przejścia od naprzemiennego wzorca zabierania głosu w mowie społecznej do jednoczesnego występowania wielu perspektyw w mowie wewnętrznej. Ponadto, jak podkreślał Wygotski, wraz ze zmianą kontekstu użycia języka z mowy społecznej na mowę prywatną i wewnętrzną zmienia się też sama funkcja języka. Na początku pełni on funkcję kierującą zachowaniem innych (mowa społeczna), a później funkcje zarządzającą i samoregulującą (mowa prywatna i wewnętrzna). Fernyhough przytacza przykład eksperymentu (za Wertsch, Stone 1985), w którym trzyipółletnie dziecko układa w obecności matki puzzle na podstawie obrazka pokazującego, co ma przedstawiać układanka po ułożeniu14:

D1: (Patrzy na obrazek, umieszcza fioletowy kawałek na właściwym miejscu.) To idzie tam, prawda? (Widzi inny purpurowy kawałek już umieszczony niepoprawnie.) O... (Patrzy na obrazek). To nie powinno iść tam, nie? Kto to tam umieścil? Nie ja. (Usuwa niepoprawnie umieszczony kawatek.)

D2: (Patrząc na obrazek) Pomocy... gdzie jest pomarańczowy kawałek? (Wskazuje na obrazek, znajduje pomarańczowy fragment). (Umieszcza pomarańczowy kawałek na właściwym miejscu.) Idzie... do rogu.

D3: (wskazuje na puste miejsce, gdzie powinien znaleźć się kawałek) Mamo, co tu powinno być? (Patrzy na obrazek.)

D4: Biały! M: Ty mi powiedz. (równocześnie) (Fernyhough 2008: 236; 2009: 45).

Fragment ten ma przedstawiać etap mowy prywatnej w rozwoju dziecka w kontekście rozwiązywania zadań poznawczych. Fernyhough do analizy tego zapisu stosuje stworzony przez siebie czteroetapowy schemat rozwojowy

${ }^{14}$ We fragmencie dialogu użyto skrótów D1-D4 na oznaczenie kolejnych wypowiedzi dziecka, M na oznaczenie wypowiedzi matki. Wyrażenia pogrubione to słowa dziecka. 
internalizacji dialogu (przedstawiony na Rysunku 1), wskazując, że tego typu dialogi są pośrednim etapem $\mathrm{w}$ internalizacji dialogu zewnętrznego (Fernyhough 2008: 237).

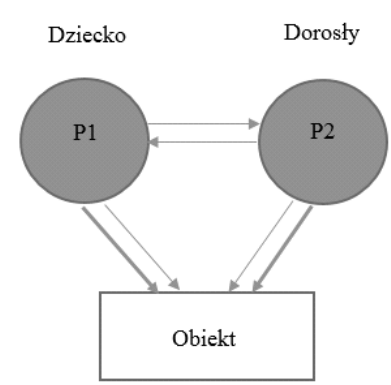

Poziom 1: Dialog zewnętrzny

Dziecko

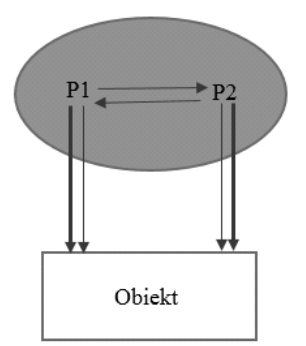

Poziom 3: Rozszerzony dialog wewnętrzny

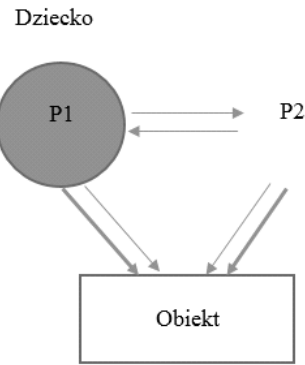

Poziom 2: Dialog wewnętrzny

Dziecko

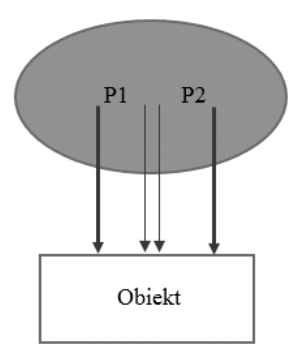

Poziom 4: Skondensowany dialog wewnętrzny

Rysunek 1. Czteropoziomowy schemat rozwoju internalizacji dialogu (za Fernyhough 2008: 237 ${ }^{15}$. Elipsy oznaczają podmioty. P1 i P2 to różne perspektywy wyrażone w dialogu. Gruba strzałka reprezentuje bezpośrednie skierowanie danej perspektywy na przedmiot. Złożenie dwóch cienkich strzałek oznacza perspektywę danego podmiotu skierowaną na perspektywę skierowaną na przedmiot; (a) częścią pierwszą takiego złożenia jest cienka strzałka od podmiotu do perspektywy (na poziomie 1 strzałka ta prowadzi od jednego podmiotu do drugiego podmiotu wraz z jego perspektywą; na poziomie 3 strzałka ta biegnie już w obrębie jednego podmiotu do zinternalizowanej perspektywy); (b) drugą częścią złożenia jest cienka strzałka prowadząca od perspektywy do przedmiotu (por. Fernyhough 2008: 235, opis Fig. 1, oraz 237).

Dialog zewnętrzny ma formę jawnego dialogu między dziećmi i opiekunami. Ma charakterystyczną strukturę rozmowy, czyli naprzemienny wzorzec zabie-

${ }_{15}$ Por. Tomasello (2002: 86, 136), gdzie formuluje się podobną koncepcję wspólnej uwagi oraz scen wspólnej uwagi. 
rania głosu (np. w formie pytanie-odpowiedź). Na drugim poziomie procesu internalizacji, na poziomie mowy prywatnej, dzieci zaczynają prowadzić i odtwarzać dialogi w postaci jawnej i głośnej mowy do siebie ${ }^{16}$. Na trzecim poziomie - rozszerzonego dialogu wewnętrznego (expanded inner dialogue) - mowa prywatna przybiera postać cichego mówienia do siebie. Na czwartym poziomie skondensowanego dialogu wewnętrznego (condensed inner dialogue) proces internalizacji jest już kompletny, co oznacza, że semiotyczno-dialogiczny proces skracania jest już zupełny (Fernyhough 2008). Mowa wewnętrzna staje się zdolnością dziecka do tworzenia i jednoczesnego przyjmowania wielu perspektyw, co odbywa się w sposób bezgłośny i przy zaniku wzorca naprzemiennego zabierania głosu. Warto zaznaczyć, że nie jest to sztywny i jednostronny schemat rozwoju. Przy zadaniach wymagających wysiłku poznawczego zjawisko mowy prywatnej u dzieci i dorosłych się nasila, co na rysunku 1 oznaczałoby przejście z poziomu 4 na poziom 3 lub 2 (Fernyhough 2008).

Fernyhough stosuje swą koncepcję do zbudowania modelu rozwojowego kompetencji rozumienia społecznego (social understanding) (Fernyhough 2008). Model myślenia dialogicznego stosuje również do wyjaśnienia zdolności związanych z rozumowaniem nieformalnym i myśleniem twórczym (Fernyhough 2009). Ponadto pojawienie się tak pojętego myślenia dialogicznego prowadzi do powstania zdolności autorefleksji i metapoznania:

internalizacja cudzych perspektyw skierowanych na moją własną perspektywę prowadzi do stworzenia „dialogowych” reprezentacji poznawczych [...], a w końcu [...], poprzez stopniową generalizację tego procesu - do możliwości monitorowania własnych procesów poznawczych (Tomasello 1999: 172) ${ }^{17}$.

Internalizacja myślenia dialogicznego umożliwia samoregulację procesów poznawczych i działania - nie tylko z własnej perspektywy, lecz także z perspektywy innych (społeczna samoregulacja w ramach intencjonalności współdzielonej) oraz z ogólniejszej perspektywy społeczno-kulturowej (normatywna samoregulacja w ramach intencjonalności kolektywnej) (Tomasello 2019). Wygotski, Fernyhough i Tomasello pokazali, że w wyjaśnianiu zdolności poznawczych istotny jest międzyosobowy poziom poznawczy (MPW) i że to na tym poziomie zachodzą określone procesy transformacji i kształtowania się zdolności poznawczych. Przykładem takich procesów może być dialogiczność myślenia i tworze-

${ }^{16}$ W drugim diagramie na Rysunku 1 brak elipsy wokół P2 oznacza, że dziecko samo odtwarza perspektywę P2; jest to również widoczne w przykładzie dziecka układającego puzzle, gdzie wypowiedzi dziecka D1 i D2 przybierają postać naprzemiennego wzorca zabierania głosu (dziecko zadaje pytanie i samo na nie odpowiada).

${ }^{17} \mathrm{Z}$ uwagi no to, że w polskim przekładzie tego fragmentu (Tomasello 2002: 230) tkwi pewna dwuznaczność, a także w celu dopasowania cytatu do kontekstu, podaję ten cytat we własnym tłumaczeniu. 
nie się nowego typu reprezentacji poznawczych - reprezentacji dialogowych. Model Wygotskiego, niezależnie od tego, czy zgadzamy się na wszystkie jego twierdzenia, w tym i tezę, że każda wyższa funkcja umysłowa ma swe źródła społeczne $^{18}$, dostarcza paradygmatycznego dla MPW schematu społecznych mechanizmów przekształcania czy transformacji umysłu i zdolności poznawczych.

\section{INTENCJONALNOŚĆ DZIELONA JAKO MIĘDZYOSOBOWY MECHANIZM TRANSFORMACJI UMYSŁU}

We współczesnej dyskusji na temat intencjonalności odróżnia się ja-intencjonalność (i-intentionality) od my-intencjonalności (we-intentionality). Ta druga może być rozumiana co najmniej na dwa sposoby, które należy od siebie odróżnić. Otóż my-intencjonalność może być częścią podmiotowości grupowej (group agency) i wówczas mówimy o intencjonalności grupowej lub częścią podmiotowości dzielonej (shared agency) i wtedy mówimy o intencjonalności dzielonej (shared intentionality) (Tollefsen 2015) ${ }^{19}$. Ponadto

18 Por. Tomasello 2015: 262: „Nie możemy sformułować żadnej wyczerpującej teorii o pochodzeniu wyjątkowego dla człowieka myślenia, która nie miałaby całkowicie społecznego charakteru. By wyrazić się tak jasno, jak to tylko możliwe: nie możemy twierdzić, że wszystkie aspekty ludzkiego myślenia są ukonstytuowane społecznie - teza ta obejmuje jedynie te aspekty, które są właściwe tylko ludzkiemu gatunkowi”.

19 Ta pierwsza związana jest z potoczną praktyką językową przypisywania stanów mentalnych nie tylko jednostkom, lecz także grupom. Przykładem może być zdanie: „Rząd podjął decyzję w sprawie ustalenia stawek podatkowych" (Tollefsen 2015, 2017). Istnienie tej powszechnej praktyki nasuwa następujące pytania: w jaki sposób powinniśmy wyjaśniać działania i własności grup? Czy wyjaśnianie zjawisk społecznych wymaga odwołania się do właściwości grup, działań grup i postaw grup? (Tollefsen 2015: 4) Głównymi stanowiskami dotyczącymi tego zagadnienia są indywidualizm metodologiczny oraz kolektywizm metodologiczny. Pierwsze stanowisko głosi, że stany oraz działania grup można wyjaśnić a zarazem zredukować do stanów, procesów i działań pojedynczych członków tych grup, tj. poszczególnych jednostek tworzących daną grupę, i do relacji zachodzących między nimi. Natomiast kolektywizm metodologiczny postuluje istnienie nieredukowalnych własności i procesów na poziomie grupy, które stanowią w wyjaśnianiu działań i stanów grupy coś więcej niż jedynie sumę działań i stanów poszczególnych jednostek ją tworzących (Tollefsen 2015: 4). Warto zaznaczyć, że kwestia podmiotowości dzielonej nie musi pociągać za sobą zagadnienia podmiotowości grupowej, ponieważ ta pierwsza dotyczy głównie zdolności jednostek do angażowania się w działania polegające na współpracy. Mówiąc o podmiotowości dzielonej, można ograniczyć się do zdań opisujących podzielanie celów, intencji lub intencjonalności; nie trzeba natomiast postulować istnienia celów, intencji czy intencjonalności jako nieredukowalnych własności grup. W literaturze nie zawsze te dwie grupy zagadnień są explicite odróżniane, a jeśli nawet tak się dzieje, to za pomocą różnych terminologii i taksonomii, por. np. Jankovic, Ludwig 2017, 
można podzielić koncepcje my-intencjonalności na filozoficzne oraz psychologiczne czy szerzej, kognitywistyczne (Żuromski 2020). Te pierwsze koncentrują się na analizie wystarczających i koniecznych warunków przypisywania stanów mentalnych podmiotowości grupowej lub na sformułowaniu wystarczających i koniecznych warunków podmiotowości dzielonej (Tollefsen 2015). Kanoniczne współczesne prace z tego zakresu to publikacje takich autorów, jak Michael Bratman, Margaret Gilbert, John Searle, Wilfrid Sellars, Raimo Tuomela (Tollefsen 2015, Schweikard, Schmid 2013). Natomiast kognitywistyczne koncepcje my-intencjonalności, jak na przykład Tomasella teoria intencjonalności dzielonej, skupione są na badaniu poznawczych i motywacyjnych zdolności do podzielania stanów umysłowych i współpracy, jak również na zagadnieniach ich ontogenezy i filogenezy (Rakoczy 2016).

W dalszej części artykułu będzie mowa tylko o jednym rodzaju my-intencjonalności, mianowicie o intencjonalności dzielonej, umożliwiającej jednostkom angażowanie się $\mathrm{w}$ działania polegające na współpracy. W wyjaśnieniu tego typu działań badacze odwołują się do takich zjawisk, jak podzielanie celów, intencji, uwagi czy intencjonalności:

Wspólna intencjonalność [intencjonalność dzielona, shared intentionality], nazywana czasem intencjonalnością zespołową, odnosi się do interakcji opartych na współpracy, których uczestnicy mają wspólny cel (wspólne zobowiązanie) i skoordynowane ze sobą zadania i role, jakie muszą odegrać realizując założony cel. [...] cele i intencje każdego z uczestników muszą zawierać w sobie coś z celów i intencji drugiego uczestnika interakcji (Tomasello i in. 2007: 278).

Koncepcje Tomasella i jego współpracowników są szczególnie interesujące, ponieważ, po pierwsze, są syntezą podejść filozoficznych i kognitywistycznych²0, a po drugie, kładą nacisk na transformatywny charakter samej intencjonalności dzielonej, a więc należą do MPW. Tego typu koncepcje Tomasello i jego współpracownicy określają mianem „Wygotskiego hipotezy inteligencji” (Moll, Tomasello 2007). W swym najogólniejszym sformułowaniu głosi ona, że „udział $\mathrm{w}$ interakcjach obejmujących dzieloną intencjonalność przekształca ludzkie poznawanie w zasadniczy sposób" (Moll, Tomasello 2007: 7). Zdaniem Tomasella teoria intencjonalności dzielonej wyjaśnia swoiste dla człowieka zdolności poznawcze (Tomasello 2015, 2016a).

Tomasello 2015, De Vecchi 2011, 2014. Niniejszy artykuł dotyczy tylko podmiotowości i intencjonalności dzielonej i odwołuje się do koncepcji i terminologii Tomasello 2015, 2016, 2019, w której intencjonalności współdzielona (joint) oraz kolektywna (collective) są częścią podmiotowości i intencjonalności dzielonej (shared).

${ }^{20}$ Tomasello opisuje swoją teorię intencjonalności dzielonej (shared intentionality theory) jako wynik „zastosowania filozoficznych pojęć intencjonalności dzielonej do zjawisk empirycznych" (Tomasello 2016c: 60). 
Tomasello i Carpenter (2007) stosują Wygotskiego hipotezę inteligencji do domeny ontogenetycznej, wykazując, że swoiste dla ludzi zdolności społeczno-poznawcze są wynikiem zderzenia się (około pierwszego roku życia) dwóch linii rozwojowych - „indywidualistycznej”, cechującej zdolności małp człekokształtnych i dzieci przed dziewiątym miesiącem życia, oraz linii rozwoju charakterystycznej dla gatunku ludzkiego ${ }^{21}$. Tę pierwszą cechuje rozwój takich zdolności poznawczych, jak rozumienie celowego działania i percepcji innych. Stanowi ona wynik adaptacji do złożonego środowiska społecznego. Tego typu społeczne zdolności poznawcze są jednak wykorzystywane przez małpy człekokształtne głównie w celu rywalizacji o pokarm, partnerów itd., a nie w celu współpracy. Druga linia rozwoju wiąże się ze specyficzną zdolnością i motywacją do podzielania stanów umysłowych z innymi - początkowo podzielania stanów emocjonalnych (około trzeciego miesiąca), a następnie stanów intencjonalnych (Tomasello 2019), czyli intencjonalnością dzieloną. $\mathrm{W}$ wyniku zderzenia tych dwóch linii rozwojowych zdolności pochodzące z linii „indywidualistycznej”, takie jak podążanie za wzrokiem innej osoby, komunikacja manipulacyjna, działanie grupowe i uczenie się społeczne, przechodzą transformację odpowiednio w zdolności: podążania za wzrokiem innej osoby w ramach wspólnej uwagi, manipulacji społecznej w komunikacji kooperatywnej, działania grupowego polegającego na współpracy i uczenia się społecznego w nauczaniu instruowanym (Tomasello, Carpenter 2007: 124).

Tomasello i Carpenter (2007) podają ponadto trzy powody, dla których pojęcie intencjonalności dzielonej jest istotnym elementem psychologii rozwojowej. Po pierwsze, wyjaśnia wyjątkowość umysłu ludzkiego, wskazując na psychologiczne podstawy tworzenia kultury (np. specyficzne procesy uczenia się i tzw. efekt zapadki). Po drugie, jako kategoria wyjaśniająca łączy ze sobą i czyni spójnymi te aspekty rozwoju, które zazwyczaj są badane osobno, np. intencjonalność, motywację czy normy społeczne. Po trzecie, umożliwia syntezę wyjaśnień odwołujących się do biologii (intencjonalność dzielona jako biologiczna adaptacja do środowiska) i kultury (intencjonalność dzielona jako zdolność do uczestniczenia w praktykach kulturowych) (Tomasello, Carpenter 2007: 124).

W swych najnowszych pracach Tomasello (2015, 2016a, 2019) rozwiną „Wygotskiego hipotezę inteligencji” i sformułował teorię intencjonalności dzielonej w odniesieniu do procesów myślenia: „Myślenie [jest] dla wspótdziałania”22.

${ }^{21}$ Szczegółowo na ten temat piszą Tomasello i in. (2007).

${ }^{22}$ Warto zauważyć, że Wygotski również kładł nacisk na rolę współpracy i myślenia, kiedy mówił o „socjogenezie wyższych funkcji psychicznych”: „wyższe funkcje psychiczne [...] powstają w procesie współpracy i społecznego współdziałania” (Wygotski 2006: 79). Tomasello (2019) określa już swoje badania jako Shared Intentionality Theory i zalicza je do A Neo-Vygotskian Theory. 
Myślenie to zespół zdolności służących do „elastycznej” samoregulacji zawierający: zdolność poznawczego reprezentowania „w umyśle” (off-line) doświadczenia dla samego siebie; zdolność „symulowania lub wyciągania wniosków przekształcających te reprezentacje na płaszczyźnie przyczynowo-skutkowej, intencjonalnej i/lub logicznej"23; zdolność samokontroli i oceny tego, w jaki sposób symulowane doświadczenia mogą prowadzić do określonych rezultatów w zachowaniu (Tomasello 2015: 18, 242) ${ }^{24}$. Teoria intencjonalności dzielonej jest zarazem teorią filogenetyczną (Tomasello 2015) oraz ontogenetyczną (Tomasello 2019)25. Strategia argumentowania na rzecz tej pierwszej opiera się na wyjaśnieniu, jak różnego rodzaju zmiany i presje ekologiczne związane - najogólniej mówiąc - z koniecznością współpracy (np. wspólne polowania) doprowadziły do zmian życia społecznego Homo sapiens. Konieczność skutecznej koordynacji działań wymagała rozwinięcia nowych zdolności komunikacji kooperatywnej, „a to łącznie umożliwiało ontogenezę, w trakcie której poszczególne osobniki mogły w ramach interakcji społecznych konstruować pewne nowe formy poznawczych reprezentacji, inferencji i samokontroli przydatne w procesie myślenia” (Tomasello 2015: 60).

Intencjonalność indywidualna (individual intentionality) to model zdolności poznawczych wspólnego przodka Homo sapiens i czlowiekowatych przystosowanego do radzenia sobie w świecie fizycznym i społecznym. Poznanie społeczne służyło mu raczej do rywalizacji niż do współpracy. Intencjonalność indywidualna jest $\mathrm{w}$ koncepcji Tomasella punktem wyjścia do formułowania hipotez dotyczących pojawienia się nowych form współpracy i komunikacji oraz ich wpływu na transformacje myślenia u ludzi pierwotnych. Intencjonalność indywidualna stanowi zatem podstawę dla zdolności transformowanych $\mathrm{w}$ wyniku pojawienia się nowych form współpracy i komunikacji. Zdaniem Tomasella historia naturalna ludzkiego myślenia miała dwa etapy. Zaszły w niej dwie transformacje zdolności poznawczych, które

23 Tomasello 2015: 18; por. tamże, 26-27: „Zdolność do symulacji i wnioskowania z przyczynowych, intencjonalnych i/lub logicznych przekształceń uzyskanych reprezentacji”.

24 Jest to ogólny model „myślenia”, który swą konkretną treść - specyficzne określenie wspomnianych wyżej trzech zdolności - uzyskuje w ramach danej intencjonalności. Np. pojęcie symulowania $\mathrm{w}$ intencjonalności indywiduowej jest związane $\mathrm{z}$ produktywnością wnioskowań i reprezentacji: „reprezentacje i inferencje poznawcze człowiekowatych są produktywne (generatywne), ponieważ mogą zasilać umysłowe symulacje, w których podmiot wyobraża sobie potencjalne sytuacje lub wyciąga wnioski na ich temat" (Tomasello 2015: 55-56).

25 Tomasello przyjmuje założenie, że ontogeneza jest powtórzeniem filogenezy, $w$ tym sensie, że sekwencja pojawiania się zdolności poznawczych (unikalnie ludzkich) w rozwoju jednostki odzwierciedla sekwencję pojawiania się tych zdolności poznawczych w procesie ewolucji (Tomasello 2019). 
można wyróżnić ze względu na pojawienie się dwóch różnych modeli wspólpracy i komunikacji:

- współpraca na małą skalę - transformacja intencjonalności indywidualnej $\mathrm{w}$ intencjonalność współdzieloną (joint intentionality) ludzi pierwotnych

- współpraca na dużą skalę - transformacja intencjonalności współdzielonej w intencjonalność kolektywną (collective intentionality) ludzi współczesnych.

Tomasello zakłada, że zdolności poznawcze wspólnego przodka małp człekokształtnych i ludzi są zbliżone do zdolności poznawczych obecnie żyjących małp czlekokształtnych, dlatego uposażenie poznawcze tych ostatnich może stanowić model empiryczny nadający się do testowania hipotez na temat zdolności poznawczych dawnego przodka ${ }^{26}$. Zdaniem Tomasella „właściwą funkcją” (by użyć sformułowania Millikan) ich uposażenia poznawczego są rywalizacyjne interakcje społeczne czy też inteligencja makiaweliczna. Aparat poznawczy małp człekoksztaltnych charakteryzuje intencjonalność indywidualna.

Model współpracy i komunikacji na małą skalę obejmuje dwuosobowe grupy ludzi pierwotnych i zdaje sprawę z myślenia drugoosobowego (secondpersonal thinking). Modelem empirycznym i polem testowania hipotez dla zdolności poznawczych ludzi pierwotnych (zanim pojawiły się kultura i język) są tym razem zdolności dzieci do współpracy i komunikacji w okresie przedjęzykowym. Zdaniem Tomasella „obligatoryjne wspólne poszukiwanie pożywienia stało się dla ludzi stabilną ewolucyjnie strategią" (Tomasello 2015: 69)27. Koordynowanie nowej formy współpracy wymagało swoistych dla człowieka pierwotnego zdolności, które Tomasello nazywa kognitywnym modelem dwupoziomowej struktury współpracy. Współpraca wymaga podzielanego celu i wspólnej uwagi, czyli tego, co stanowi sedno intencjonalności współdzielonej (joint), w ramach której uczestnicy mogli przyjmować indywidualne role i indywidualne perspektywy. Wspólne doświadczenie ludzi pierwotnych w ramach intencjonalności współdzielonej (joint) stanowi punkt odniesienia - dwuosobowy wspólny grunt - który umożliwia nową formę komunikacji kooperatywnej, taką jak ge-

26 Por. krytykę tego założenia w (Moll 2016).

${ }^{27}$ Choć Tomasello nie poświęca wiele uwagi odpowiedzi na pytanie, kiedy mogło dojść do tej istotnej transformacji, to stawia hipotezę, że mogło to mieć miejsce 400 tysięcy lat temu, w czasie występowania Homo heidelbergensis, wspólnego przodka Neandertalczyków i ludzi współczesnych. Mają za tym przemawiać dane paleoantropologiczne świadczące o umiejętnościach Homo heidelbergensis polowania na duże zwierzęta czy używania narzędzi, które wymagały współpracy, a ponadto o gwałtownym wzroście mózgu i populacji (Tomasello 2015: 69). 
sty wskazywania i pantomima. Najważniejszym elementem w opisie intencjonalności współdzielonej (joint) jest ukazanie tego, jak w ramach owego kognitywnego modelu dwupoziomowej struktury wspólpracy jego cechy transformatywne wpływają na tworzenie nowego typu reprezentacji (perspektywiczność, symboliczność, quasi-propozycjonalność), wnioskowań (społeczna rekurencyjność, kombinatorycznośćer) oraz samokontroli (samokontrola kooperatywna, samokontrola komunikacyjna), co w rezultacie doprowadza do transformacji intencjonalności indywidualnej w myślenie perspektywicznorekurencyjno-drugoosobowe, tj. intencjonalność współdzieloną (joint).

Takie czynniki jak wzrost populacji, rywalizacja na poziomie grup czy konieczność komunikacji z nieznanymi osobnikami wewnątrz grupy doprowadziły do konieczności współpracy na dużą skalę:

kolejny krok naprzód musiał polegać na „skolektywizowaniu” tego „skooperatywizowanego" poznania i myślenia przez skonwencjonalizowanie i zinstytucjonalizowanie a więc także znormatywizowanie i zobiektywizowanie - niemal wszystkiego (Tomasello 2015: 139).

Powstanie konwencjonalnych praktyk kulturowych jako nowych form współpracy oraz komunikacji konwencjonalnej jako nowej formy koordynacji owej współpracy - tym razem już w ramach wspólnego gruntu kulturowego - przekształciły istniejące cechy myślenia intencjonalności współdzielonej (joint) w myślenie bezstronne (agent-neutral thinking), myślenie obiektywno-refleksyjno-normatywne, tj. intencjonalność kolektywną. Teorię intencjonalności dzielonej podsumowuje Tabela 1.

\begin{tabular}{|c|c|c|c|}
\hline \multirow{2}{*}{ Intencjonalność } & \multirow{2}{*}{$\begin{array}{l}\text { Intencjonalność } \\
\text { indywidualna }\end{array}$} & \multicolumn{2}{|c|}{ Intencjonalność dzielona (shared) } \\
\hline & & $\begin{array}{c}\text { Intencjonalność } \\
\text { współdzielona (joint) }\end{array}$ & $\begin{array}{l}\text { Intencjonalność } \\
\text { kolektywna }\end{array}$ \\
\hline $\begin{array}{l}\text { Główne cechy } \\
\text { intencjonalności } \\
\text { (myślenia) }\end{array}$ & $\begin{array}{l}\text { współzawodnictwo, } \\
\text { intencjonalna ko- } \\
\text { munikacja }\end{array}$ & $\begin{array}{l}\text { dwupoziomowa współ- } \\
\text { praca, kooperatywna } \\
\text { komunikacja }\end{array}$ & $\begin{array}{l}\text { kultura zorientowana } \\
\text { na grupę, konwencjo- } \\
\text { nalna komunikacja }\end{array}$ \\
\hline Reprezentacje & $\begin{array}{l}\text { schematyczne/obra- } \\
\text { zowe reprezentacje }\end{array}$ & $\begin{array}{l}\text { perspektywiczne/sym- } \\
\text { boliczne reprezentacje }\end{array}$ & $\begin{array}{l}\text { obiektywne/konwen- } \\
\text { cjonalne reprezentacje }\end{array}$ \\
\hline Wnioskowania & $\begin{array}{l}\text { przyczynowo-skut- } \\
\text { kowe/intencjonalne }\end{array}$ & $\begin{array}{l}\text { społecznie }{ }^{29} \text { rekuren- } \\
\text { cyjne }\end{array}$ & $\begin{array}{l}\text { refleksyjne/umotywo- } \\
\text { wane }\end{array}$ \\
\hline Samokontrola & $\begin{array}{l}\text { samokontrola po- } \\
\text { znawcza }\end{array}$ & $\begin{array}{l}\text { samokontrola drugo- } \\
\text { osobowa }\end{array}$ & $\begin{array}{l}\text { samozarządzanie nor- } \\
\text { matywne }\end{array}$ \\
\hline
\end{tabular}

Tabela 1. Teoria intencjonalności dzielonej (Tomasello 2015: 242)

${ }^{28}$ Kombinatoryczność jest tu rozumiana jako zdolność łączenia gestów w celu porozumienia się z innymi (Tomasello 2015: 129).

${ }^{29}$ Por. Tomasello 2015: 18, 20, 63, 102, 127-128. 
Zarysowana tu teoria dzielonej intencjonalności Tomasella jest interesującą propozycją modelu na poziomie MPW w domenach: ontogenetycznej, filogenetycznej i kulturowej, a jej sednem są różne formy społecznych źródeł i transformacji zdolności poznawczych, takich jak reprezentowanie, wnioskowanie oraz samokontrola.

\section{MPW JAKO POZIOM SPOŁECZNYCH MECHANIZMÓW TRANSFORMACJI UMYSŁU}

Jak widzieliśmy, zarówno ustalenia teoretyczne, jak i empiryczne wskazują, że istnieją społeczne fakty poznawcze, które wymagają uwzględnienia w badaniach nad umysłem i poznaniem. Przez tezę o faktach MPW będę dalej rozumiał twierdzenie, że istnieją społeczne dziedziny powstawania, rozwijania i transformacji zdolności poznawczych jednostki opisywane za pomocą modeli Wygotskiego, Fernyhougha oraz Tomasella. W szczególności wyższe funkcje poznawcze (przeciwdziedzina T) mają swe źródła w interakcjach międzyosobowych, ustrukturyzowanych przez mechanizmy transformujące, takie jak intencjonalność dzielona czy dialogiczność. Owe interakcje wpływają na elementarne zdolności i procesy poznawcze, prowadząc do ich transformacji w bardziej zaawansowane zdolności i procesy poznawcze (por. Tabela 2):

\begin{tabular}{|c|c|c|c|c|}
\hline $\begin{array}{c}\text { Rodzaj } \\
\text { transformacji (T) }\end{array}$ & Model & Dziedzina T & Proces T & Przeciwdziedzina $T$ \\
\hline T1 & Wygotskiego & $\begin{array}{l}\text { niższe funkcje } \\
\text { umysłowe }\end{array}$ & $\begin{array}{l}\text { międzyosobowe } \\
\text { interakcje, } \\
\text { internalizacja, } \\
\text { mediacja } \\
\text { semiotyczna }\end{array}$ & $\begin{array}{l}\text { wyższe funkcje umy- } \\
\text { słowe }\end{array}$ \\
\hline T2 & Fernyhougha & $\begin{array}{l}\text { dialog } \\
\text { zewnętrzny }\end{array}$ & $\begin{array}{l}\text { międzyosobowe } \\
\text { interakcje, } \\
\text { internalizacja, } \\
\text { mediacja } \\
\text { semiotyczna }\end{array}$ & $\begin{array}{l}\text { dialog wewnętrzny, } \\
\text { myślenie dialogiczne }\end{array}$ \\
\hline T3 & Tomasella & $\begin{array}{l}\text { intencjonalność } \\
\text { indywiduowa }\end{array}$ & $\begin{array}{l}\text { międzyosobowe } \\
\text { interakcje, } \\
\text { internalizacja } \\
\text { i dzielona in- } \\
\text { tencjonalność }\end{array}$ & $\begin{array}{l}\text { intencjonalność } \\
\text { współdzielona } \\
\text { (joint), intencjonal- } \\
\text { ność kolektywna }\end{array}$ \\
\hline
\end{tabular}

Tabela 2. Modele społecznych mechanizmów transformacji umysłu 
Jeżeli teza o faktach MPW jest zasadna, to istnieją podstawy do sformułowania tezy metodologicznej MPW: istnieje względnie autonomiczna dziedzina badania wyodrębniona przez interakcje międzyosobowe o charakterze transformacyjnym, do których wyjaśnienia postulowany jest MPW.

W celu eksplikacji tak sformułowanego MPW przyjmuję pewne założenia o charakterze metodologicznym. Przede wszystkim zakładam analizę wielopoziomową umysłu: poziomy wyjaśniania PPW, SPW i MPW są względnie autonomiczne, w tym przynajmniej sensie, że stanowią autonomiczne dziedziny badania empirycznego i teoretycznego. Autonomiczność MPW, PPW i SPW oznacza jednak nie izolacjonizm eksplanacyjny, lecz dynamiczną interakcję między poziomami, którą można zrozumieć dzięki badaniom interdyscyplinarnym czy też transdyscyplinarnym. Przykładem dziedziny badawczej, w której wyjaśnienie uwzględnia dynamiczną interakcję poziomów MPW, PPW i SPW, jest neuronauka społeczna pojmowana jako „wieloaspektowa próba zrozumienia mechanizmów leżących u podstaw zachowań społecznych dzięki łączeniu podejścia biologicznego i społecznego" (Cacioppo, Berntson 2002). Tak zdefiniowana dziedzina badania wymaga zasad porządkujących i kodyfikujących relacje zachodzące między poziomami biologicznymi i społecznymi. Zbiór takich zasad jest skodyfikowany w koncepcji wielopoziomowej analizy integracyjnych wpływów i zachowań społecznych (multi-level integrative analyses of social influences and behavior) (Cacioppo, Berntson 2002, Przybysz 2014).

Jak widać, głównym celem neuronauki społecznej jako dziedziny badawczej jest zrozumienie i wyjaśnienie mechanizmów odpowiedzialnych za powstawanie zachowań społecznych (wyjaśnianie należy rozumieć zgodnie z mechanistycznymi koncepcjami wyjaśniania, por. Bechtel, Richardson 1993, Bechtel 2008, Craver 2009). Wyjaśnienie danego zjawiska polega na sformułowaniu hipotezy dotyczącej mechanizmów leżących u jego podstaw, a „mechanizm danego zjawiska składa się z bytów i działań, zorganizowanych w taki sposób, że są one odpowiedzialne za to zjawisko" (Illari, Williamson 2011: 120). Choć w naukach społecznych również wypracowano - co najmniej od lat siedemdziesiątych ubiegłego wieku - podejście do wyjaśniania opartego na mechanizmach, to obecna postać tej strategii wyjaśniania wywodzi się z badań kognitywistycznych głównie na terenie biologii i to z tego obszaru wiedzy została przeszczepiona do dziedziny tego co społeczneз3:

Grupy społeczne można również rozumieć jako mechanizmy, w których ludzie i podgrupy są elementami mechanizmu, a relacje, które między nimi zachodzą, mają charakter

3o Por. Ylikoski (2012, 2018). Przegląd koncepcji wyjaśniania opartego na mechanizmach w naukach społecznych zawiera (Hedström, Ylikoski 2010). 
międzyosobowy, jak w przypadku komunikacji. Jak wskazuje przyjęcie antropologii w poczet dyscyplin kognitywistyki, ta właśnie dziedzina jest otwarta na włączenie społecznego wymiaru myślenia, tak że skupienie uwagi na mechanizmach społecznych jest naturalną częścią kognitywistyki (Thagard 2013: 600).

Thagard $(2008,2013)$ łączy koncepcję wyjaśniania opartą na mechanizmach (mechanism-based explanation) oraz analizę wielopoziomową w postaci pluralizmu eksplanacyjnego, traktując redukcjonizm („istnieje podstawowy poziom wyjaśnień” czy „każdy wyższy poziom redukuje się do następnego niższego poziomu”) oraz antyredukcjonizm („wyższe poziomy są w dużej mierze niezależne od niższych poziomów") jako nieprzekonujące strategie wyjaśniania w naukach kognitywnych. Zdaniem Thagarda mechanizmy są hierarchicznie wielopoziomowe, tj. „byty i działania wyższego poziomu są niezbędne do zrozumienia bytów i działań na niższych poziomach i vice versa, a zjawiska psychiczne najlepiej wyjaśnia integracja różnych poziomów" (Thagard 2008: 7). Thagard (2008) stosuje tę strategię do ukazania mechanizmów leżących u podstaw tych form myślenia, które angażują emocje i są odpowiedzialne za takie działania, jak m.in. podejmowanie decyzji, rozumowanie prawnicze, odkrycia naukowe i przekonania religijne. Zrozumienie i wyjaśnienie tego typu działań i procesów poznawczych wymaga zintegrowania różnych poziomów wyjaśniania: molekularnego, neuronalnego, psychologicznego i społecznego (por. tab. 3).

\begin{tabular}{|c|c|c|c|c|}
\hline Mechanizmy & Elementy & Relacje & Interakcje & Zmiany \\
\hline Społeczne & $\begin{array}{l}\text { osoby i grupy } \\
\text { społeczne }\end{array}$ & $\begin{array}{l}\text { stowarzyszenie, } \\
\text { członkostwo }\end{array}$ & komunikacja & $\begin{array}{l}\text { wpływ, } \\
\text { decyzje grupowe }\end{array}$ \\
\hline Psychologiczne & $\begin{array}{l}\text { reprezentacje } \\
\text { mentalne, takie } \\
\text { jak pojęcia }\end{array}$ & $\begin{array}{l}\text { składniki, } \\
\text { skojarzenia, } \\
\text { implikacje }\end{array}$ & komunikacja & wnioskowania \\
\hline Neuronalne & $\begin{array}{l}\text { neurony, grupy } \\
\text { neuronalne }\end{array}$ & $\begin{array}{l}\text { połączenia } \\
\text { synaptyczne }\end{array}$ & $\begin{array}{l}\text { wzbudzenie, } \\
\text { zahamowanie }\end{array}$ & $\begin{array}{l}\text { aktywność } \\
\text { mózgu }\end{array}$ \\
\hline Molekularne & $\begin{array}{l}\text { cząsteczki, takie } \\
\text { jak neuroprze- } \\
\text { kaźniki i białka }\end{array}$ & $\begin{array}{l}\text { składniki, połą- } \\
\text { czenie fizyczne }\end{array}$ & $\begin{array}{l}\text { reakcje bioche- } \\
\text { miczne }\end{array}$ & $\begin{array}{l}\text { transformacja } \\
\text { cząsteczek }\end{array}$ \\
\hline
\end{tabular}

Tabela 3. Składniki mechanizmów umysłowych (Thagard 2008, 2013: 602)

Integracja nie polega tu na redukcji kolejnych poziomów do pewnego wyróżnionego poziomu wyjaśniania (np. z poziomu społecznego do psychologicznego i następnie do neuronalnego, a w końcu molekularnego), lecz raczej na wyjaśnieniu, które obejmuje wszystkie poziomy jednocześnie. Ponadto mamy tu do czynienia z przyczynowym wyjaśnianiem w obie strony: „z góry 
na dół”, gdy np. interakcja społeczna między dwojgiem ludzi z danej grupy społecznej wzbudza strach zwiększający poziom kortyzolu (hormonu stresu) oraz „Z „dołu do góry”, gdy ten zwiększony poziom kortyzolu zmienia interakcję społeczną (Thagard 2008: 8).

$\mathrm{Z}$ punktu widzenia postulowanego MPW istotne jest to, że Thagard (2008) pokazuje, jak włączyć mechanizmy społeczne w wyjaśnianie zdolności poznawczych i umysłu. MPW można odczytać jako tezę dotyczącą rozbudowania hipotez metodologicznych pluralizmu eksplanacyjnego oraz wpływu społeczno-kulturowych mechanizmów na formowanie się umysłu i poznania. Główna teza w tym kontekście brzmi następująco: wyjaśnienie tej relacji wymaga postulowania względnie autonomicznego, międzyosobowego poziomu wyjaśniania, którego głównym przedmiotem badania są społeczne mechanizmy transformacji umysłu.

Jak zatem rozumieć kategorię tego co społeczne w kontekście MPW? Istnieją podstawy filogenetyczne i ontogenetyczne, ukazane m.in. w teorii intencjonalności dzielonej, aby interakcje międzyosobowe traktować jako punkt wyjścia w badaniach społecznych mechanizmów transformacji umysłu. Choć procesy „interpsychologiczne” (zwłaszcza interakcje triadyczne typu: matkaprzedmiot-dziecko) zostały przedstawione jako paradygmatyczny przypadek społecznych interakcji MPW, nie oznacza to, że wyczerpują one całą dziedzinę tego co społeczne ${ }^{3}$. W istocie kategoria tego co spoleczne, a tym samym i społecznych mechanizmów, jest złożona i wymaga analizy wielopoziomowej. Istnieją koncepcje socjologiczno-psychologiczne, które proponują analizę różnych poziomów tego co społeczne oraz ich wpływu na jednostkę w kontekście rozwojowym. Przykładem takiej koncepcji jest model ekologiczny Uriego Bronfenbrennera (Meadows 2011). Innym przykładem jest np. koncepcja Emergence Paradigm R. Keitha Sawyera (2005, 2011), która z punktu widzenia postulowanego MPW byłaby propozycją ukazującą poziomy społecznych mechanizmów transformacji umysłu. Na przykład, zgodnie z tą koncepcją intencjonalność współdzielona (joint) oraz intencjonalność kolektywna egzemplifikują różne poziomy społecznych mechanizmów transformacji umysłu $^{32}$ (por. Rysunek 2).

${ }^{31}$ Wielu autorów konceptualizuje procesy „interpsychologiczne” w różny sposób, jako intersubiektywność (pierwsza, druga, trzecia, za Traverthenem), sceny wspólnej uwagi (Tomasello 2002), relacje intencjonalne (Barresi, Moore 1996), trójkąt epistemiczny (Chapman 1991, Carpendale, Lewis 2004, 2006) relatedness triangle (Hobson 1994, 2002).

${ }^{22} \mathrm{O}$ ile intencjonalność współdzielona (joint) egzemplifikuje poziom B mechanizmów transformacji umysłu, o tyle intencjonalność kolektywna egzemplifikuje poziom E. 


\begin{tabular}{|l|}
\multicolumn{1}{c|}{ Struktura społeczna (poziom E) } \\
teksty pisemne (procedury, prawa, przepisy); systemy materialne i infrastruktura (archi- \\
tektura, projektowanie urbanistyczne, sieci komunikacyjne i transportowe)
\end{tabular}

Rysunek 2. Paradygmat emergencji Sawyera (The Emergence Paradigm)

Jakich aspektów umysłu dotyczy teza o MPW? Model Wygotskiego i Tomasella „koncentruje się nie tyle na całej ludzkiej psychologii, ile na unikalnie ludzkiej psychologii i wyjaśnia tę unikalność ludzkiej psychologii głównie w kategoriach unikalnych form aktywności społeczno-kulturowej, w które jednostki angażują się w trakcie życia" (Tomasello 2019: 304). Mechanizmy transformacji umysłu badane na MPW leżą u podstaw specyficznie ludzkich form umysłu i poznania. Tak więc transformacja dotyczy nie tyle wszystkich zdolności umysłowych oraz form interakcji i praktyk społecznych, ile tych charakterystycznych dla człowieka. Egzemplifikacją tej tezy jest wyjaśnienie w ramach MPW powstawania, rozwijania i transformacji reprezentacji poznawczych. Istnieją swoiste dla MPW mechanizmy tworzenia reprezentacji poznawczych, na przykład dialogicznych, jak intencjonalność współdzielona (joint) i intencjonalność kolektywna.

A zatem dzięki jakim procesom to co społeczne staje się częścią indywidualnego funkcjonowania poznawczego? Postulowanie MPW zobowiązuje do pewnego porządku wyjaśniania, który najlepiej jest uchwycony w ogólnym prawie genetycznym rozwoju kulturowego Wygotskiego, a który można ująć $\mathrm{w}$ haśle: First between, then within. W istocie jest to teza dotycząca socjogenezy specyficznych dla człowieka zdolności poznawczych, czyli teza wskazująca społeczne, międzyosobowe mechanizmy transformacyjne leżące u podstaw tych zdolności. Jednym z podstawowych procesów jest internalizacja, która umożliwia nie tylko rekonstrukcję praktyk społecznych (np. myślenie dialogiczne) na poziomie psychologicznym, lecz także reorganizację tego poziomu przez nabywanie perspektyw uczestników owych 
praktyk33. Tak pojęta internalizacja umożliwia m.in. ocenę własnych procesów poznawczych i działania z punktu widzenia innych osób, co może prowadzić do wytworzenia się specyficznych metazdolności: refleksji i samoregulacji (Tomasello 2019, Fernyhough 2008, Białecka-Pikul 2012).

\section{ZAKOŃCZENIE}

Współcześnie duża część odpowiedzi na pytanie o to, na czym polega wpływ tego co społeczne w konstytuowaniu umysłu i poznania, związana jest $\mathrm{z}$ rozwijaniem koncepcji extended mind lub extended cognition o element społeczny czy społeczno-kulturowy, gdzie umysł czy poznanie są „rozproszone” (distributed) (Hutchins 1995), „podparte rusztowaniem” (scaffolded, Sterelny 2010) czy też społecznie rozszerzone (socially extended, mental institutions) (Gallagher, Crisafi 2009, Gallagher 2013). Można również jednak przyjąć bardziej minimalistyczne rozwiązanie, postulując $w$ ramach analizy wielopoziomowej oraz mechanistycznych koncepcji wyjaśniania międzyosobowy poziom wyjaśniania. Podstawowym celem badawczym na tym poziomie jest zrozumienie społecznych mechanizmów transformacji umysłu.

Oczywiście przedstawiony opis MPW jest tylko pierwszym krokiem $\mathrm{w}$ stronę systematycznego ujęcia. Uzupełnienia wymaga zwłaszcza wskazanie procesów leżących u podstaw teorii umysłu czy społecznego rozumienia w kontekście MPW (por. Przybysz 2014), tym bardziej że obecnie można zaobserwować zmianę podejścia badaczy do tego zagadnienia - zmianę, którą można scharakteryzować jako przejście od „ery Piageta” do „ery Wygotskiego” (Białecka-Pikul 2012).

Widać również, jak ważna w badaniach interdyscyplinarnych jest współpraca. Poszukiwania przez Tomasella i jego zespół społecznych mechanizmów transformacji umysłu i zdolności poznawczych doprowadziły do operacjonalizacji modeli teoretycznych różnych form współpracy, opracowanych przez filozofów, takich jak Michael Bratman, John Searle czy Marie Gibert. Rola filozofów i kognitywistów w tej współpracy może polegać nie tylko na dostarczaniu teoretycznych modeli procesów poznawczych, lecz także na formułowaniu wyjaśnień z MPW dotyczących społecznych mechanizmów transformacji

33 Wśród kontynuatorów idei Wygotskiego oraz przedstawicieli nurtu psychologii kulturowej, m.in. na łamach czasopisma "Culture \& Psychology”, toczy się spór o rozumienie pojęcia internalizacji. Krótki przegląd stanowisk w tym sporze zawiera (Zittoun, Gillespie 2015). Współczesną propozycję opracowania tego pojęcia przedstawia Tomasello (2019), a krytyczne uwagi do tej koncepcji formułuje m.in. Fernyhough (2005). 
umysłu. Wyjaśnienia tego typu będą sprowadzały się do formułowania hipotez na temat konkretnych mechanizmów międzyosobowych, jak np. intencjonalność dzielona, jako hipotez empirycznych. Również sama złożona kategoria tego co społeczne wymaga analizy pod kątem mechanizmów transformacji umysłu.

\section{BIBLIOGRAFIA}

Barresi J., Moore C. (1996), Intentional Relations and Social Understanding, „Behavioral and Brain Sciences" 19(1), 107-122. https://doi.org/10.1017/So140525X00041790

Bąk W. (2009), Wielość Ja w ujęciu poznawczym i dialogowym. Próba integracji podejšć, „Przegląd Psychologiczny” 52(1), 53-68.

Bechtel W., Richardson R. (1993), Discovering Complexity. Decomposition and Localization as Strategies in Scientific Research, Cambridge, MA: The MIT Press. http://dx.doi.org/ 10.7551/mitpress/8328.001.0001

Bechtel W. (2008), Mental Mechanisms. Philosophical Perspectives on Cognitive Neuroscience, London: Routledge. http://dx.doi.org/10.4324/9780203810095

Białecka-Pikul M. (2012), Narodziny i rozwój refleksji nad myśleniem, Kraków: Wydawnictwo Uniwersytetu Jagiellońskiego.

Białek A. (2010), Patrz, gdzie patrzę. Psychologiczne aspekty podejmowania cudzej perspektywy, Kraków: Wydawnictwo Uniwersytetu Jagiellońskiego.

Berk L. E. (1992), Children's Private Speech. An Overview of Theory and the Status of Research [w:] Private Speech. From Social Interaction to Self-Regulation, R. M. Diaz, L. E. Berk (eds.), Hillsdale, NJ: Erlbaum, 17-43.

Cacioppo J. T., Berntson G. G. (2002), Social Neuroscience [w:] Foundations in Social Neuroscience, J. T. Cacioppo et al. (eds.), Cambridge, MA: The MIT Press, 1-9. https://doi.org/10.7551/mitpress/3077.001.0001

Carpendale J. I. M., Lewis C. (2004), Constructing an Understanding of Mind. The Development of Children's Understanding of Mind within Social Interaction, „Behavioral and Brain Sciences” 27(1), 79-150. https://doi.org/10.1017/S0140525X04000032

Carpendale J. I. M., Lewis C. (2006), How Children Develop Social Understanding, Oxford: Blackwell.

Carpendale J. I. M., Frayn M., Kucharczyk P. (2016), The Social Formation of Human Minds [w:] The Routledge Handbook to the Philosophy of the Social Mind, J. Kiverstein (ed.), London: Routledge, 139-151.

Chapman M. (1991) The Epistemic Triangle. Operative and Communicative Components of Cognitive Development [w:] M. Chandler, M. Chapman (eds.), Criteria for Competence. Controversies in the Conceptualization and Assessment of Children's Abilities, Hillsdale, NJ: Erlbaum, 209-228.

Craver C. F. (2009), Explaining the Brain. Mechanisms and the Mosaic Unity of Neuroscience, Oxford: Oxford University Press.

De Vecchi F. (2011), Collective Intentionality vs. Intersubjective and Social Intentionality. An Account of Collective Intentionality as Shared Intentionality, „Phenomenology and Mind" 1, 72-87. 
De Vecchi F. (2014), Three Types of Heterotropic Intentionality. A Taxonomy in Social Ontology [w:] Institutions, Emotions, and Group Agents. Contributions to Social Ontology, A. Konzelmann Ziv, H. B. Schmid (eds.), Dordrecht: Springer, 117-137.

Drayson Z. (2012), The Uses and Abuses of the Personal/Subpersonal Distinction, „Philosophical Perspectives" 26(1), 1-18. https://doi.org/10.1111/phpe.12014

Drayson Z. (2014), The Personal/Subpersonal Distinction, „Philosophy Compass” 9(5), 338-346. https://doi.org/10.1111/phc3.12124

Fernyhough C. (1996), The Dialogic Mind. A Dialogic Approach to the Higher Mental Functions, „New Ideas in Psychology” 14, 47-62. https://doi.org/10.1016/0732-118X (95)00024-B

Fernyhough C. (1997), Vygotsky's Sociocultural Approach. Theoretical Issues and Implications for Current Research [w:] The Development of Social Cognition, S. Hala (ed.), Hove: Psychology Press, 65-93.

Fernyhough C. (2005), What Is Internalised? Dialogic Cognitive Representations and the Mediated Mind, „Behavioral and Brain Sciences” 28(5), 698-699. https://doi.org/ 10.1017/So140525X05300124

Fernyhough C. (2008), Getting Vygotskian about Theory of Mind. Mediation, Dialogue, and the Development of Social Understanding, „Developmental Review” 28(2), 225262. https://doi.org/10.1016/j.dr.2007.03.001

Fernyhough C. (2009), Dialogic Thinking [w:] Private Speech, Executive Functioning, and the Development of Verbal Self-Regulation, A. Winsler, C. Fernyhough, I. Montero (eds.), Cambridge: Cambridge University Press, 42-52. https://doi.org/10.1017/CBO 9780511581533.004

Hedström P., Ylikoski P. (2010), Causal Mechanisms in the Social Sciences, „Annual Review of Sociology” 36, 49-67. https://doi.org/10.1146/annurev.soc.012809.102632

Hobson P. (1993), Autism and the Development of Mind, London: Erlbaum.

Hobson P. (2002), The Cradle of Thought. Exploring the Origins of Thinking, London: MacMillan.

Hutchins E. (1995), Cognition in the Wild, Cambridge, MA: The MIT Press.

Gallagher S. (2013), The Socially Extended Mind, „Cognitive Systems Research” 25-26, 4-12. https://doi.org/10.1016/j.cogsys.2013.03.008

Gallagher S., Crisafi A. (2009), Mental Institutions, „Topoi” 28(1), 45-51. https://doi.org/ 10.1007/s11245-008-9045-O

Gauvain M., Perez S. (2015), Cognitive Development and Culture [w:] Handbook of Child Psychology and Developmental Science. Cognitive Processes, L. S. Liben, U. Müller, R. M. Lerner (eds.), New York: Wiley Blackwell, 854-896. https://doi.org/10.1002/ 9781118963418.childpsy220

Illari P.M., Williamson J. (2011), Mechanisms Are Real and Local [w:] Causality in the Sciences, P. M. Illari, F. Russo, J. Williamson (eds.), New York: Oxford University Press, 818-844. http://dx.doi.org/10.1093/acprof:oso/9780199574131.003.0038

Jankovic M., Ludwig K. (eds.) (2017), The Routledge Handbook of Collective Intentionality, New York: Routledge. https://doi.org/10.4324/9781315768571

Kern A., Moll H. (2017), On the Transformative Character of Collective Intentionality and the Uniqueness of the Human, „Philosophical Psychology” 30(3), 319-337. https:// doi.org/10.1080/09515089.2017.1295648

Kielar-Turska M. (2013), Językowa zewnętrzna i wewnętrzna kontrola działania, „Psychologia Rozwojowa" 18(4), 47-61. 
Meadows S. (2009), The Child as Social Person, London: Routledge-Taylor and Francis. https://doi.org/10.4324/9780203861059

Moll H. (2016), Tension in the Natural History of Human Thinking, „Journal of Social Ontology" 2(1), 65-73. https://doi.org/10.1515/jso-2015-0043

Moll H., Tomasello M. (2007), Cooperation and Human Cognition. The Vygotskian Intelligence Hypothesis, „Philosophical Transactions of the Royal Society B: Biological Sciences" 362(1480), 639-648. https://doi.org/10.1098/rstb.2006.2000

Müller U., Jacques S., Brocki K., Zelazo P. (2009), The Executive Function of Language in Preschool Children [w:] Private Speech, Executive Functioning, and the Development of Verbal Self-Regulation, A. Winsler, C. Fernyhough, I. Montero (eds.), Cambridge: Cambridge University Press, 53-68. https://doi.org/10.1017/CBO9780511581533.005

Poczobut R. (2009), Między redukcją a emergencją. Spór o miejsce umystu $w$ świecie fizycznym, Wrocław: Wydawnictwo Uniwersytetu Wrocławskiego.

Przybysz P. (2014), O poznawaniu innych umysłów. Wokót kognitywistycznych badań nad poznaniem spotecznym, Poznań: Bogucki Wydawnictwo Naukowe.

Puchalska-Wasyl M. (2016), Nasze wewnętrzne dialogi. O dialogowości jako sposobie funkcjonowania czlowieka, Torun: Wydawnictwo Naukowe Uniwersytetu Mikołaja Kopernika.

Rakoczy H. (2016), The Development of Individual and Shared Intentionality [w:] The Routledge Handbook to the Philosophy of the Social Mind, J. Kiverstein (ed.), London: Routledge, 139-151.

Schweikard D. P., Schmid H. B. (2013), Collective Intentionality [w:] The Stanford Encyclopedia of Philosophy (Summer 2013 Edition), E. N. Zalta (ed.), http://plato.stanford. edu/entries/collective-intentionality.

Sawyer R. K. (2005), Social Emergence. Societies as Complex Systems, Cambridge: Cambridge University Press. http://dx.doi.org/10.1017/CBO9780511734892

Sawyer R. K. (2011), Conversation as Mechanism. Emergence in Creative Groups [w:] Analytical Sociology and Social Mechanisms, P. Demeulenaere (ed.), Cambridge: Cambridge University Press, 78-96. http://dx.doi.org/10.1017/CBO 9780511921315.005

Searle J. (2010), Making the Social World. The Structure of Human Civilization, New York: Oxford University Press. https://doi.org/10.1093/acprof:osobl/9780195396171. 001.0001

Sterelny K. (2010), Minds. Extended or Scaffolded?, „Phenomenology and the Cognitive Sciences" 9, 465-481. https://doi.org/10.1007/s11097-010-9174-y

Thagard P. (2008), Hot Thought. Mechanisms and Applications of Emotional Cognition, Cambridge, MA: Bradford Book-The MIT Press.

Thagard P. (2013), Cognitive Science [w:] The Routledge Companion to Philosophy of Science, S. Psillos, M. Curd (eds.), London-New York: Routledge, 596-608.

Tollefsen D. (2015), Groups as Agents, Cambridge: Polity Press.

Tollefsen D. (2017), Collective Intentionality and Methodology in the Social Sciences [w:] The Routledge Handbook of Collective Intentionality, M. Jankovic, K. Ludwig (eds), New York: Routledge, 389-401. http://dx.doi.org/10.4324/9781315768571-37

Tomasello M. (1999), The Cultural Origins of Human Cognition, Cambridge: Harvard University Press.

Tomasello M. (2002), Kulturowe źródta ludzkiego poznawania, tłum. J. Rączaszek, Warszawa: Państwowy Instytut Wydawniczy.

Tomasello M. (2015), Historia naturalna ludzkiego myślenia, tłum. B. Kucharzyk, R. Ociepa, Kraków: Copernicus Center Press. 
Tomasello M. (2016a), A Natural History of Human Morality, Cambridge, MA: Harvard University Press. https://doi.org/10.4159/9780674915855

Tomasello M. (2016b), Dlaczego wspótpracujemy?, tłum. Ł. Kwiatek, Kraków: Copernicus Center Press.

Tomasello M. (2016c), Precís of A Natural History of Human Thinking, „Journal of Social Ontology" 2(1), 59-64. https://doi.org/10.1515/jso-2015-0041

Tomasello M. (2016d), Response to Commentators, „Journal of Social Ontology” 2(1), 117123. https://doi.org/10.1515/jso-2015-0042

Tomasello M. (2019), Becoming Human. A Theory of Ontogeny, Cambridge, MA: Harvard University Press. https://doi.org/10.4159/9780674988651

Tomasello M., Carpenter M. (2007), Shared Intentionality, „Developmental Science” 10(1), 121-125. https://doi.org/10.1111/j.1467-7687.2007.00573.x

Tomasello M., Carpenter M., Call J., Behne T., Moll H. (2007), Rozumienie i wspólnota intencji jako źródła kulturowego poznawania [w:] Wspólnota komunikacyjna $w$ teorii i praktyce, B. Sierocka (red.), Wrocław: Oficyna Wydawnicza ATUT, 260-324.

Toomela A. (2016), What Are Higher Psychological Functions?, „Integrative Psychological and Behavioral Science” 50(1), 91-121. https://doi.org/10.1007/s12124-015-9328-o

Valsiner J., van der Veer R. (2000), The Social Mind. Construction of the Idea, Cambridge: Cambridge University Press.

Wertsch J. V. (1985), Vygotsky and the Social Formation of Mind, Cambridge, MA: Harvard University Press.

Wertsch J. V., Stone C. A. (1985), The Concept of Internalization in Vygotsky's Account of the Genesis of the Higher Mental Functions [w:] Culture, Communication, and Cognition. Vygotskian Perspectives, J. V. Wertsch (ed.), Cambridge: Cambridge University Press.

Winkielman P. (2008), Psychologia społeczna a neuronauki. Dominacja, separacja czy satysfakcjonujący związek?, „Psychologia Społeczna” 3(1) [6], 11-22.

Wygotski L. S. (1971), Wybrane prace psychologiczne, tłum. E. Flesznerowa, J. Fleszner, Warszawa: Państwowe Wydawnictwo Naukowe.

Wygotski L. S. (1989), Myślenie i mowa, tłum. E. Flesznerowa, J. Fleszner, Warszawa: Państwowe Wydawnictwo Naukowe.

Wygotski L. S. (2006), Narzędzie i znak $w$ rozwoju dziecka, tłum. B. Grell, Warszawa: Wydawnictwo Naukowe PWN.

Ylikoski P. (2012), Micro, Macro, and Mechanisms [w:] The Oxford Handbook of Philosophy of the Social Sciences, H. Kincaid (ed.), Oxford: Oxford University Press, 21-45. https://doi.org/10.1093/oxfordhb/9780195392753.013.0002

Ylikoski P. (2018), Social Mechanisms [w:] The Routledge Handbook of Mechanisms and Mechanical Philosophy, S. Glennan, P. Illar (eds.), New York: Routledge, 401-412. https://doi.org/10.4324/9781315731544-30

Zittoun T., Gillespie A. (2015), Internalization. How Culture Becomes Mind, „Culture \& Psychology" 21(4), 477-491. https://doi.org/10.1177/1354067X15615809

Żuromski D. (2016), Towards Explanation of the Natural Origins of Content, „Kultura i Edukacja" 2, 112-127.

Żuromski D. (2020), Therapeutic vs Constructive Approach to the Transformative Character of Collective Intentionality. The Interpersonal Level of Explanation, „Logic and Logical Philosophy", w druku, opublikowane online (Online First) 19 lutego 2020, 1-31. https:// doi.org/10.12775/LLP.2020.004 